\title{
Financial Statement Outcomes When Alternative Derivative Hedging Designations Exist
}

\author{
Arlette C. Wilson (E-mail: Awilson@Business.Auburn.Edu), Auburn University \\ Ronald L. Clark (E-mail: Clarkrl@ Auburn.Edu), Auburn University \\ William Pugh, Auburn University
}

\begin{abstract}
When alternate reporting methods exist, financial statement preparers tend to select methods that provide more favorable results. Certain hedging transactions may be designated as either a fair value hedge or a cash flow hedge. Both designations achieve the objective of matching the gain $\langle$ loss > on the derivative with the loss <gain> on the hedged item in the same reporting period. However, the cash flow hedge accounting tends to create a greater appearance of equity volatility.
\end{abstract}

\subsection{Introduction}

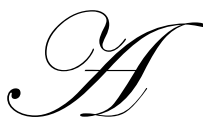

ccording to the efficient market hypothesis (EMH), the market for securities can be described as efficient if it reflects all available information and reacts instantaneously to new information. The EMH holds that an investor cannot make an excess return by knowledge of particular pieces of information. When accounting standards allow for alternative accounting methods for the same transaction, companies must disclose in footnotes to the financial statements which method they applied. If the market is truly efficient, it should not matter which method is selected since the supplemental information may be utilized to adjust the financial statements as necessary for comparability purposes. That is, an efficient market cannot be fooled by merely selecting one method as opposed to an alternate method for reporting a financial transaction.

Whether the market is efficient or not, often times it appears that preparers of financial statements do not believe the market is truly efficient. They believe they can fool the market by recording a transaction with the alternative method that provides the greater reported net income or other more favorable financial statement presentation. For example, many companies have incurred significant costs structuring business combinations to satisfy the 12 criteria to account for a combination as a pooling-of-interest. The only reasonable explanation for this uneconomical decision is that the company believes it can fool the market by recording the business combination to avoid a future earnings hit from goodwill amortization required by the purchase method. Another example of an uneconomical decision includes the use of FIFO during an inflationary period (LIFO would reduce tax burden) because it results in a higher reported net income.

Statement on Financial Accounting Standards No. 133 provides comprehensive accounting for derivatives and hedging activities. Some hedging activities may qualify as either a fair value hedge or a cash flow hedge, so companies must designate the type of hedge at the inception of the hedging transaction. Since companies tend to select alternatives that result in a more favorable financial statement presentation, preparers may be interested in financial statement outcomes from applying alternative hedging designations. The purpose of this paper is to investigate whether there is a financial statement presentation preference when alternative hedging designations exist.

Readers with comments or questions are encouraged to contact the authors via email.

Two examples are used to illustrate the potential financial statement outcomes when selecting between a cash flow and fair value hedge designation. Investors generally do not view major fluctuations in equity favorably. 
Therefore, companies may prefer a more stable earnings and a more stable equity to minimize impact on their stock price. A company that is maintaining a relatively stable earnings pattern and prefers equity to reflect this stability may prefer a fair value hedge designation since cash flow hedges tend to create an appearance of equity volatility.

\subsection{Basic Accounting for Hedging Activities}

SFAS \#133 requires that all derivatives be marked to fair value and reported as assets or liabilities on the Statement of Financial Position. The change in fair value is included in current earnings unless the derivative qualifies for hedge accounting. The underlying concept of hedge accounting is that the gain/loss on the derivative be included in current earnings in the same period as the loss/gain on the hedged item.

For a fair value hedge, the derivative and hedged item are both adjusted for changes in value with the offsetting gains and losses included in current earnings. Only the ineffective part of the hedge affects earnings. However, for a cash flow hedge, the derivative gain/loss is initially included as a separate component of equity and later removed and included in earnings when the hedged item affects earnings. This including in and removing from equity may create an appearance of equity volatility. The accounting for a fair value hedge and cash flow hedge are discussed below.

\subsection{Fair Value Hedge}

A derivative that hedges the exposure to changes in the fair value of a recognized asset or liability or of a firm commitment may qualify as a fair value hedge. For example, fixed-rate debt has a fair value exposure since the fair value of the debt will vary as interest rates vary. To hedge this fair value exposure, the company could enter into an interest rate swap to receive a fixed rate and pay a variable rate on a stated notional amount equivalent to the principal amount of the debt. The fixed rate received from the swap would be used to pay the fixed rate on the debt and the variable rate paid on the swap would represent the interest paid on the debt. The swap would effectively convert the fixed-rate debt to a variable rate and hedge the fair value exposure. The interest rate swap would qualify as a fair value hedge of the recognized liability.

The change in the fair value of a derivative designated as a fair value hedge is included in current earnings in the period of change. Current earnings also includes the offsetting change in the fair value of the hedged item attributable to the risk being hedged. For example, assume a fixed-rate receive, variable-rate pay interest rate swap is designated as a fair value hedge of a fixed-rate debt. Assume the interest rate decreases by financial statement date. The decrease in the interest rate will cause the fair value of the company's debt to increase resulting in a loss. The fair value of the swap increases resulting in a gain since the company will receive more than it pays. The gain on the derivative offsets the loss on the debt. Both the gain and loss are included in current earnings. If the gain and loss are not perfectly offset, the ineffective part of the hedge affects earnings.

\subsection{Cash Flow Hedge}

A derivative that hedges an exposure to variable cash flows may qualify as a cash flow hedge. The variable cash flows can be associated with an existing asset or liability or with a forecasted transaction. For example, variable-rate debt has exposure to variable cash flows since cash outflows for interest varies as interest rates vary. To hedge this cash flow exposure, the company could enter into an interest rate swap to receive a variable rate and pay a fixed rate on a stated notional amount equivalent to the principal amount of the debt. The variable rate received from the swap is used to pay the variable rate on the debt and the fixed rate paid on the swap would represent the interest paid on the debt. The swap would effectively convert the variable-rate debt to a fixed rate and hedge the cash flow exposure. The interest rate swap would qualify as a cash flow hedge of the existing liability.

The change in fair value of the derivative which represents the effective portion of the hedge is included in other comprehensive income. That is, the cumulative change in fair value of the derivative from inception of the hedge that offsets cumulative change in expected future cash flows of the hedged item is reported as other comprehensive income and accumulates in equity. Any ineffective portion of the hedge is included in current earnings. For 
example, the intrinsic value of a put option hedging the future sale of stock represents the effective portion of the hedge since it hedges the change in expected future cash flow of the future sale. Any change in time value of the option does not directly hedge the future cash flow of the sale of the stock and is therefore included in current earnings.

The accumulated other comprehensive income (AOCI) resulting from a cash flow hedge is removed from equity and included in earnings when the hedged item affects earnings. If the hedged item is variable-rate debt, the hedged item affects earnings when interest expense is recorded. AOCI is periodically removed from equity and included as an adjustment to interest expense to effectively convert interest expense from the variable rate to the fixed rate. If the hedged item is the forecasted purchase of raw materials, the hedged item affects earnings when the finished product is sold and the cost of the raw materials appears in the cost of goods sold. If the hedged item is the forecasted purchase of equipment, the hedged item affects earnings when the equipment is depreciated.

\subsection{Financial Statement Impact When Alternative Designations Exist}

The purpose of hedge accounting is to include the offsetting gains and losses of the hedged item and hedging instrument in earnings in the same period. The fair value hedge accomplishes this objective by including the change in fair value of the derivative and hedged item in earnings as the change occurs. However, the hedged item of a cash flow hedge may not affect earnings until a future period. Therefore, the change in fair value of the derivative is accumulated into equity until the hedged item affects earnings. The moving of the derivative gains/losses in and out of equity may create an appearance of equity volatility. Even though both hedges accomplish the offsetting of gains and losses in earnings in the same period, companies may prefer designating a fair value hedge when the option exists to avoid the appearance of equity volatility associated with the cash flow hedge.

Two examples are presented below to help illustrate the financial statement impact of applying the two alternative accounting methods in situations that would allow the designation of either a cash flow or fair value hedge. The discussion focuses on the effects on net income and equity since all derivatives must be marked to fair value and reported as an asset or liability regardless of designation.

\subsection{Options to Hedge Inventory}

On November 1, 2000, Company X purchased 100,000 widgets at $\$ 10$ each. By December 1, 2000 the widgets had increased in value to $\$ 14$ each. Wanting to preserve this appreciation in value, on this date Company $\mathrm{X}$ purchased a put option to sell 100,000 widgets at a price of $\$ 14$ each. The cost of the option was $\$ 50,000$. At December 31, the fair value of the inventory decreased by $\$ 2$ each and fair value of the option was $\$ 235,000$. On February 28,2001 the inventory was sold for $\$ 1,100,000$ and the option was settled. ${ }^{1}$

The hedge of inventory may be designated as a hedge of the fair value exposure of the recognized asset inventory. Alternately, the hedge may be designated as a cash flow hedge of the forecasted sale of the inventory. Exhibit 1 displays the journal entries if the option is designated as a fair value hedge, while Exhibit 2 includes journal entries if designated as a cash flow hedge.

Assuming a fair value hedge, the options are marked to fair value with the change in fair value included in earnings. The inventory is not adjusted to its fair value, but is adjusted for the change in its fair value during the hedge period (\$14 to \$12). Although not necessary, the gain/loss on the option is separated into its change in time value ( $\$ 15,000$ loss) and change in intrinsic value $(\$ 200,000$ gain) for illustrative purposes. The change in intrinsic value of the options is the offset to the change in inventory value since inception of the hedge. At February 28, 2001, the gain from sale of the inventory is calculated from the carrying value of the inventory and the option is settled at the difference between strike price of $\$ 14$ and the fair value of $\$ 11$ on settlement date.

Assuming a cash flow hedge, the options are marked to fair value. The change in fair value attributable to intrinsic value represents the change in expected future cash flows of the sale of the inventory and is therefore in- 
cluded in other comprehensive income (OCI) and accumulated in equity. The change in fair value of the options attributable to time value is included in current earnings. When the inventory is sold in 2001 and affects earnings, the OCI is removed from equity and included in earnings.

Both hedge designations accomplish the goal of hedge accounting which is to include the gain $\langle$ loss $>$ on the hedged item and loss <gain> on the hedging instrument in earnings in the same period. However, to accomplish this earnings match, a cash flow hedge initially accumulates the gain or loss in accumulated other comprehensive income (AOCI) and later removes this gain or loss and includes it in earnings when the hedged item affects earnings.

EXHIBIT 1 Fair Value Hedge of Inventory

\begin{tabular}{|c|c|c|c|c|}
\hline \multirow[t]{2}{*}{ November 1, 2000} & \multirow[t]{2}{*}{ Inventory } & \multicolumn{3}{|c|}{$1,000,000$} \\
\hline & & Cash & & $1,000,000$ \\
\hline \multirow[t]{2}{*}{ December 1, 2000} & Options & 50,000 & & \\
\hline & & Cash & & 50,000 \\
\hline \multirow[t]{5}{*}{ December 31, 2000} & Options & 185,000 & & \\
\hline & Loss (P\&L) & & 15,000 & \\
\hline & & Gain (P\&L) & & 200,000 \\
\hline & Loss (P\&L) & & 200,000 & \\
\hline & & Inventory & & 200,000 \\
\hline \multirow[t]{6}{*}{ February 28, 2001} & Cash & & $1,100,000$ & \\
\hline & & Inventory & & 800,000 \\
\hline & & Gain (P\&L) & & 300,000 \\
\hline & Cash & & 300,000 & \\
\hline & & Options & 235,000 & \\
\hline & & Gain $(P \& L)$ & & 65,000 \\
\hline
\end{tabular}

EXHIBIT 2 Cash Flow Hedge Of Forecasted Sale Of Inventory

\begin{tabular}{|c|c|c|c|c|}
\hline \multirow[t]{2}{*}{ November 1, 2000} & \multirow[t]{2}{*}{ Inventory } & \multicolumn{3}{|c|}{$1,000,000$} \\
\hline & & Cash & & $1,000,000$ \\
\hline \multirow[t]{2}{*}{ December 1, 2000} & Options & 50,000 & & \\
\hline & & Cash & & 50,000 \\
\hline \multirow[t]{3}{*}{ December 31, 2000} & Options & 185,000 & & \\
\hline & Loss $(\mathrm{P} \& \mathrm{~L})$ & & 15,000 & \\
\hline & & Gain $(\mathrm{OCI})$ & & 200,000 \\
\hline \multirow[t]{8}{*}{ February 28, 2001} & Cash & & $1,100,000$ & \\
\hline & & Inventory & & $1,000,000$ \\
\hline & & Gain (OCI) & & 100,000 \\
\hline & Gain (OCI) & & 300,000 & \\
\hline & & Gain $(\mathrm{P} \& \mathrm{~L})$ & & 300,000 \\
\hline & Cash & & 300,000 & \\
\hline & & Options & 235,000 & \\
\hline & & Gain $(P \& L)$ & & 65,000 \\
\hline
\end{tabular}

A fair value hedge designation would probably be more compatible with a strategy of stable earnings and stable equity. Exhibits 3 and 4 illustrate the effects of both the fair value hedge and the cash flow hedge on earnings and total stockholders' equity, respectively, when a company has relatively stable earnings. The effect on stock- 
holders' equity is the amount of earnings for a fair value hedge. The effect on stockholders' equity is the amount of earnings as well as the gains and losses flowing through OCI. The temporary inclusion of the gain in OCI and reclassification into earnings in a later period when earnings are relatively stable may give equity an appearance of volatility. And the greater the change in fair value of the derivative, the greater the volatility.

\section{EXHIBIT 3 Comparison of Effects on Earnings of Fair Value Hedge and Cash Flow Hedge for Put Option}

Year 2000

\begin{tabular}{|c|c|c|c|}
\hline & $\begin{array}{l}\text { Fair Value } \\
\text { Hedge }\end{array}$ & & $\begin{array}{l}\text { Cash Flow } \\
\text { Hedge }\end{array}$ \\
\hline Income before gains <losses> & $\$ 1,000,000$ & & $\$ 1,000,000$ \\
\hline Gain <Loss> on Option & 185,000 & & $\langle 15,000\rangle$ \\
\hline$<$ Loss > on inventory & & $\leq 200,000\rangle$ & $\ldots$ \\
\hline Income before tax & & $\$ 985,000$ & $\overline{\$ 985,000}$ \\
\hline
\end{tabular}

Year 2001

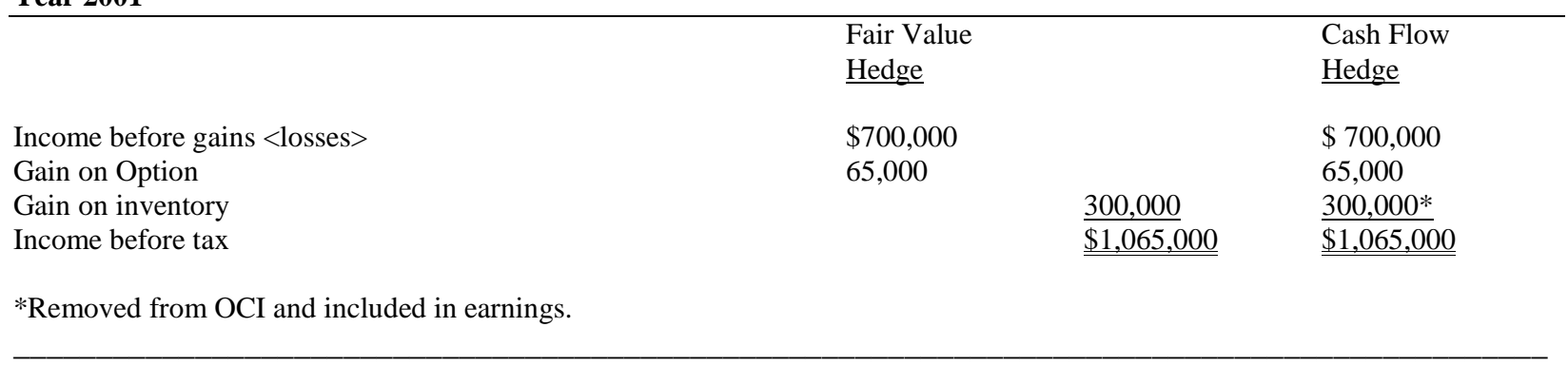

EXHIBIT 4 Comparison Of Effects On Stockholders' Equity Of Fair Value Hedge And Cash Flow Hedge For Put Option

\begin{tabular}{lll}
\hline Year & Fair Value Hedge & Cash Flow Hedge \\
2000 & $\$ 985,000$ & $\$ 1,185,000$ \\
2001 & $1,065,000$ & 865,000 \\
\hline
\end{tabular}

Although selection of one designative versus the other does not allow earnings management, a company could manage equity to a certain extent by selecting a cash flow hedge if the hedge crosses financial statement dates. The initial cost of an option is expensed over the life of the option. Otherwise an option only results in a gain. If the option is out of the money the intrinsic value is zero. But if the option is in the money, the intrinsic value is positive. Therefore a cash flow hedge with an option results in possible increases in OCI in one period and corresponding decreases in OCI in a later period when the hedged item affects earnings. Knowing for certain the direction of the effect on OCI may allow equity management.

Generally, if the derivative is an option and the hedge crosses financial statement dates, earnings is unaffected by hedge designation. However, if a company has stable earnings and prefers to have stable equity or if a company wants the change in equity to reflect the change in earnings, the fair value hedge would better accomplish these goals. A cash flow hedge would increase equity in one period and decrease equity in a later period while having no affect on earnings. If management prefers a more stable equity in times of increasing earnings, the decreasing of OCI in a later period could offset the greater earnings a help in managing equity. 


\subsection{Swap to Hedge an Asset/Liability Mismatch}

A company has an asset/liability mismatch when loan receivables provide fixed-rate cash inflows while debt requires variable-rate payments or when loans are variable-rate while debt is fixed-rate. A company can hedge this asset/liability mismatch by entering into an interest rate swap that receives the type of rate paid on the debt and pays the type of rate received on the loans. The interest rate swap can be designated as a hedge of either the loans or the debt.

On January 1, 2000, Company X has $\$ 80,000,000$ of 3-year 6\% loan receivables and $\$ 100,000,000$ of 5 year debt tied to LIBOR plus .5 percent with rate reset each December 31. Concerned that rates may rise and the loans will not provide enough cash inflow to pay the debt, Company $\mathrm{X}$ enters into a 3 -year interest rate swap to receive LIBOR and pay 6 percent on a notional of $\$ 60,000,000$ with settlement and rate reset annually on December 31. This swap represents a partial hedge and can be designated as a fair value hedge of the loans or a cash flow hedge of the debt. ${ }^{2}$

Many firms use interest rate swaps to manage the payment structure of their liabilities. (Chance, p. 587) This example uses the interest rate swap to convert the variable-rate debt to a fixed rate since cash inflows from loans are fixed. Swaps are considerably easier to use than transactions in the underlying securities. They are less costly and the paperwork and legal requirements are less burdensome. (Chance, p. 587).

Exhibit 5 provides the changing LIBOR and related fair values of the swap and loans for a 2-year period of time. A confirmed letter of credit exists which eliminates potential risk of default by either counterparty. Therefore the fair value of the swap is based solely on interest rate risk. Exhibit 6 and 7 include the journal entries assuming a fair value hedge and cash flow hedge, respectively. The journal entries focus only on $\$ 60,000,000$ of the loans and debt since this is the amount being hedged.

\section{EXHIBIT 5 LIBOR and Fair Values}

\begin{tabular}{llll}
\hline Date & $\underline{\text { LIBOR }}$ & $\begin{array}{l}\text { Fair Value* } \\
\text { Swap }\end{array}$ & $\begin{array}{l}\text { Fair Value } \\
\text { Loans }\end{array}$ \\
January 1, 2000 & $6.0 \%$ & $\$--$ & $\$--$ \\
December 31, 2000 & $7.0 \%$ & $1,084,810$ & $58,888,800$ \\
December 31, 2001 & $7.5 \%$ & 837,209 & $59,162,800$ \\
\hline
\end{tabular}

*The fair value of the swap is estimated as the current receivable position held constant for remainder of contract, discounted back at a risk-free rate assumed to be LIBOR.

Assuming a fair value hedge of the fixed-rate loans, the swap is marked to fair value with the unrealized gain included in current earnings. The carrying value of the hedged loans are also adjusted for change in fair value attributable to the change in interest rates. Although not a perfect offset, the gain on the swap offsets the loss on the loans.

The interest revenue for 2001 is based on a yield of 7 percent which is the rate reflected in the carrying value reported at December 31, 2000. The swap settlement is $\$ 600,000$ at December 31, 2001 since 7 percent is received while 6 percent is paid on the notional of $\$ 60,000,000$. The swap and loans are again adjusted for fair value changes.

EXHIBIT 6 Fair Value Hedge of Fixed-Rate Loans

\begin{tabular}{llll}
\hline December 31, $2000 \quad$ Cash & Interest Revenue & $3,600,000$ & $3,600,000$
\end{tabular}




\begin{tabular}{|c|c|c|c|}
\hline & $\begin{array}{c}\text { Interest Expense } \\
\text { Cash }\end{array}$ & $3,900,000$ & $3,900,000$ \\
\hline (Adjusting) & Gain (P\&L) & $1,084,810$ & $1,084,810$ \\
\hline (Adjusting) & $\begin{array}{l}\text { Loss (P\&L) } \\
\text { Discount-Loan }\end{array}$ & $1,111,200$ & $1,111,200$ \\
\hline December 31, 2001 & Interest Revenue & $3,600,000$ & $3,600,000$ \\
\hline & $\begin{array}{l}\text { Discount-Loan } \\
\text { Interest Revenue }\end{array}$ & 522,200 & 522,200 \\
\hline & $\begin{array}{c}\text { Interest Expense } \\
\text { Cash }\end{array}$ & $4,500,000$ & $4,500,000$ \\
\hline & Cash & 600,000 & 600,000 \\
\hline (Adjusting) & Gain (P\&L) & 352,399 & 352,399 \\
\hline (Adjusting) & $\begin{array}{l}\text { Loss (P\&L) } \\
\text { Discount-Loan }\end{array}$ & 248,200 & 248,200 \\
\hline
\end{tabular}

EXHIBIT 7 Cash Flow Hedge of Variable-Rate Debt

\begin{tabular}{|c|c|c|c|}
\hline \multirow[t]{4}{*}{ December 31, 2000} & Cash & $3,600,000$ & \\
\hline & Interest Revenue & & $3,600,000$ \\
\hline & Interest Expense & $3,900,000$ & \\
\hline & Cash & & $3,900,000$ \\
\hline \multirow[t]{2}{*}{ (Adjusting) } & Swap & $1,084,810$ & \\
\hline & Gain $(\mathrm{OCI})$ & & $1,084,810$ \\
\hline \multirow[t]{4}{*}{ December 31, 2001} & Cash & $3,600,000$ & \\
\hline & Interest Revenue & & $3,600,000$ \\
\hline & Interest Expense & $4,500,000$ & \\
\hline & Cash & & $4,500,000$ \\
\hline \multirow[t]{4}{*}{ (Adjusting) } & Gain $(\mathrm{OCI})$ & 600,000 & \\
\hline & Interest Expense & & 600,000 \\
\hline & Cash & 600,000 & \\
\hline & Swap & & 600,000 \\
\hline \multirow[t]{2}{*}{ (Adjusting) } & Swap & 352,399 & \\
\hline & Gain (OCI) & & 352,399 \\
\hline
\end{tabular}

Assuming a cash flow hedge of the variable-rate debt, the swap is marked to fair value, but the unrealized gain flows through other comprehensive income and accumulates in equity. Since the reset dates for LIBOR are the same for both the swap and debt, there is no hedge ineffectiveness that would affect earnings. In 2001, an amount 
necessary to reduce interest expense to 6.5 percent (rate effectively converted to) is removed from AOCI and included in earnings. The $\$ 600,000$ swap settlement is recorded and then the swap is adjusted to its current fair value. The change in fair value is again reported as OCI.

Exhibit 8 illustrates the effect of the two hedge designations on earnings assuming that the company is experiencing relatively stable earnings. Both hedge designations match the gain on the swap with the loss (reported as an adjustment to interest) on the hedged item in the same period. However, the earnings impact is not identical for both hedge designations because the fair value hedge includes some hedge ineffectiveness, while the cash flow hedge does not.

EXHIBIT 8 Comparison of Effects on Earnings of Fair Value Hedge and Cash Flow Hedge for Interest Rate Swap

Year 2000

$\underline{\text { Fair Value Hedge }}$

Income before Interest and Gains <Losses>

Interest Revenue

Interest Expense

Gain on Swap

Loss on Loan

Income before Tax
$\$ 1,300,000$

$3,600,000$

$<3,900,000\rangle$

$1,084,810$

$\leq 1,111,200>$

$\underline{\$ 973,610}$ $\underline{\text { Cash Flow Hedge }}$

$\$ 1,300,000$

$3,600,000$

$<3,900,000>$

--

$\$ 1,000,000$

Year 2000

Fair Value Hedge

$\$ 1,300,000$

and Gains < Losses>

Interest Revenue

Interest Expense

Gain on Swap

Loss on Loan

Income before Tax

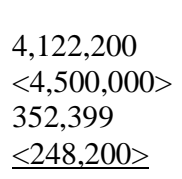

$\$ 1,026,399$ $\underline{\text { Cash Flow Hedge }}$

$\$ 1,300,000$

3,600,000

$<3,900,000>$

$--$

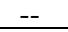

Exhibit 9 presents the effects of the two hedge designations on total stockholders' equity. The cash flow hedge initially includes the change in fair value in AOCI until it is needed for matching purposes in earnings at which time it is reclassified. The greater the swings in fair value of the swap, the greater the swings in AOCI. In this example, the interest rate continued to increase from 6 percent to 7 percent to 7.5 percent. If the rate had initially increased and then dropped, the swing in equity would have been greater. Therefore, if a company is experiencing stable earnings and prefers stable equity, the fair value hedge designation may be more compatible with their strategy.

\section{EXHIBIT 9 Comparison of Effects on Stockholders' Equity of Fair Value Hedge and Cash Flow Hedge for Interest Rate Swap}




\begin{tabular}{|c|c|c|c|}
\hline Year & & Fair Value Hedge & Cash Flow Hedge \\
\hline 2000 & & $\$ 973,610$ & $\$ 2,084,810$ \\
\hline 2001 & $1,026,399$ & 752,399 & \\
\hline
\end{tabular}

Unlike options in the previous example, the swap can result in either gains or losses and the inclusion and removal from AOCI may extend over several accounting periods. Therefore the change in fair value of the swap can either increase or decrease equity, with reversal in later periods. Since the direction of the effect on equity is not predictable as with the one-sided derivative, options, it would be difficult for management to use the cash flow hedge designation to help manage equity.

\subsection{Generalizations Regarding Designation Selection}

A company whose earnings, and therefore equity, tend to vary with no consistent pattern or stability would probably be indifferent as to hedge designation since both a cash flow and fair value hedge have the same total effect on earnings and total stockholders' equity over the life of the hedge. However, if a company is using a hedging strategy to maintain a stable earnings pattern and wants equity to reflect this stability, then the company may prefer the fair value designation when alternatives exist.

Both the fair value and cash flow hedges achieve the objective of matching the gain <loss> on the derivative with the loss <gain> on the hedged item in the same period. Any hedge ineffectiveness is included in current earning for both designations. The accounting difference is that the fair value hedge matches the gains and losses in earnings as the derivative changes value, but the cash flow hedge initially reports the change in fair value of the derivative in AOCI and later includes it in earnings when the hedged item affects earnings. Different hedging instruments and how they may affect a company's strategy are discussed below.

\subsection{Options}

Options or derivatives with option-like characteristics such as Caps and Floors are one-sided. That is, they will always result in a gain. If a cash flow hedge is designated, this gain is initially included in AOCI and later removed when the hedged item affects earnings. The greater the change in fair value, the greater the increase in AOCI and subsequent decrease. If the duration of the option contract extends into subsequent accounting periods, equity may have an appearance of volatility if earnings are otherwise relatively stable. Since AOCI always initially increases with subsequent decreases because of the one-sided nature of options, management may be able to use the cash flow designation to help manage equity.

\subsection{Interest Rate Swaps}

Interest rate swaps differ from options in that they are two-sided which means they can result in gains or losses. So management cannot predict which direction equity will swing as a result of changes in AOCI when a cash flow hedge is designated.

The longer the duration of the contract, the more periods affected and the greater the opportunity for fair value swings. A cash flow designation results in amounts being removed from AOCI for matching purposes to adjust the interest each period and amounts being included in AOCI for current changes in fair value of the swap. If a stable earnings and equity strategy is based on interest expense <revenue> that exists at the time of hedging, either designation will maintain the earnings strategy, but equity will fluctuate with the cash flow hedge designation. And the greater the changes in the interest rate, the greater the fluctuation.

\subsection{Futures and Forward Contracts}


Futures and forward contracts are also two-sided resulting in either gains or losses. For a cash flow hedge, amounts are included in AOCI until the contract matures. These amounts are removed from AOCI and included in earnings when the hedged item affects earnings which could be all in one period (purchase of raw materials is included as cost of good sold) or several periods (purchase of equipment is included as depreciation expense).

If the hedging activity is part of a company's strategy to maintain a stable earnings pattern, and therefore stable equity, the company may prefer a fair value hedge. Either hedge will maintain the stable earnings since the gains and losses offset for both designations. However, the cash flow hedge initially includes the gains <losses> in AOCI before matching them in earnings with the hedged item's losses $<$ gains $>$ creating a fluctuation in equity.

\subsection{Conclusion}

One objective of financial accounting standard-setters is to narrow reporting alternatives so as to increase comparability between firms. However, some alternative methods still exist and financial statement preparers tend to select those methods that present a more favorable financial outcome. In selected situations, SFAS \#133 allows for a hedging transaction to be designated as either a fair value hedge or a cash flow hedge. Both hedge designations result in the same effect on total earnings and total stockholders' equity over the life of the hedged transaction. Both hedge designations match the gain <loss> on the derivative with the loss <gain> on the hedged item in earnings for each period. However, the cash flow hedge initially reports the change in fair value of the derivative in AOCI and later removes it to match with the loss <gain> on the hedged item.

Companies concerned with investor reaction to equity volatility may maintain a strategy of stable earnings and equity. These companies may prefer a fair value hedge designation which avoids the appearance of equity fluctuation associated with the accounting for a cash flow hedge. Otherwise, companies may be indifferent as to which hedge designation is selected.

\subsection{Suggestions for Future Research}

This paper suggests that theoretically companies would probably designate a fair value hedge for those hedges in which alternative designations exist. Future research could focus on analyzing financial statements of companies involved in hedging activities to determine if, in fact, they are selecting the fair value hedge designation when the cash flow hedge is an acceptable alternative designation.

\section{References}

1. Financial Accounting Standards Board (FASB). 1998. Statement of Financial Accounting Standards No. 133 Accounting for Derivative Instruments and Hedging Activities. Norwalk, CT: FASB.

2. Chance, D.M. 2001. An Introduction to Derivatives and Risk Management. $5^{\text {th }}$ ed. New York: Harcourt College Publishers.

3. KPMG. 1998. Derivatives and Hedging Handbook. New York: KPMG.

\footnotetext{
Footnotes

${ }^{1}$ A risk management transaction similar to this one may be found in Derivatives and Hedging Handbook, KPMG Peat Marwick LLP, 1998, page 137.

${ }^{2}$ Similar risk management strategies may be found in Derivatives and Hedging Handbook, KPMG Peat Marwick LLP, 1998 , pages 120 and 193.
} 